\title{
ORTA ÇAĞDA ERZURUM KALESI
}

Gürsoy SOLMAZ*

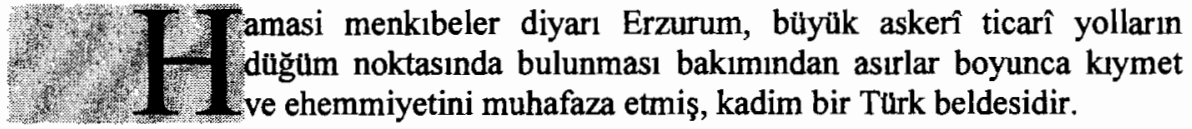

Erzurum Kalesi'nin tarihi de şehrin tarihi ile at başı yưrüyecek kadar eskidir. Bu şehre sahip ve hâkim olan milletlerin Erzurum Kalesi'nde paylan vardır. Çalışmalarımızda tedkik ettigimiz Avnik, Tortum, Oltu ve dið̧er kaleler de bőyledir.

Erzurum şehri, haliyle Erzurum Kalesi birinci derecede ehemmiyetli yolların dügüm noktasında bulunması ve mevkiinin müdafaaya elverişli olması sayesinde, tarihinin devamı boyunca bazen askerî, bazen de ticarî ehemmiyeti ön planda gelmek üzere büyluk bir rol oynamıştır. Gerçekten Erzurum, Kafkasya ve İran'dan gelen büyük yolların Anadolu'ya açılan yegâne giriş kapısını teşkil etmekte olduğundan, illk ve Ortaçağlarda şarktan Anadolu'ya girmek teşebbüsünde bulunana istilâ ordulanna karşı Anadolu mủdafaasının mukadderatını tâyin eden başlıca kale olmak bakımından, büyuk bir önem kazanmış ve Roma- Iran, daha sonra Bizans, Selçuklu imparatorluklarının rekabeti burada karşılaşmıştır.

Erzurum, tarihi boyunca askeri bir şehir ve bir çok zamanlar da bir serhad şehri olmuştur. Doğu Roma ile İran arasında yapılan büyük savaşlarda Erzurum bir hudut kalesi idi. Birçok defalar doğudan gelen akınlar Erzurum onlerinde karşılanmıştır. Mutlaka bu nedenledir ki şehrin zikzaklı bir kaderi vardır.

Erzurum şehrinin bulundugu mevkiide kurulmasının sebebi, yalnız ovanın Kara-Su yatağına yakın bataklık ve feyezana mâruz alçak sahasından uzak, kendisine bol su te'min eden dağların eteginde bulunması ile değil, üzerinde daha eski çağlardan beri İç-Kale'nin yukselmekte bulunduğu münferit tepenin mevcûdiyeti ile izah edilmek lâzım gelir. ${ }^{1}$ seçmişlerdir ${ }^{2}$

Erzurum şehrini kuranlar, bir hisar yeri olarak, işte bu tabii araziyi

Mevkiinin merkeziliği sebebiyle, Ortaçağ'da büyük bir ehemmiyeti kazanmış Erzurum'un adı; XI. asır ortasında Selçuklular tarafından tahrip edilmiş

\footnotetext{
* Atatürk Üniv. Fen-Edebiyat Fak. Tarih Bölümü Ögretim Üyesi.

${ }^{1}$ Besim Darkot,"Erzurum.” Mad. İA. C.IV.s.340.

${ }^{2}$ Besim Darkot, a.g.e., s.340.
} 
olan Arzen'in Meyafarikin ile Siirt arasındaki Erzen'dan ayırmak tizere Anadolu'ya aidiyetini belirtecek Rûm kelimesi ilâve edilerek, Erzen-al Râm denilmesinden çıkmışıır ${ }^{3}$

Bugün şehrin uç kat surundan yalnız İç Kale ile dış surlara ait yıkılmamış birkaç duvar parçası ve surdan açılan kapıların adları (Tebriz Kapı, Gürcü Kapı, Erzincan Kapı,Yeni Kapı ) kalmıștır. İç- Kale'nin esas duvarları bugün de şehrin manzarasına hâkim bulunmaktadır. Evliya Çelebi'de 210 kule ve 2080 bedenli olarak anılan İ̧ Kale'nin güneybatı ucunda, şehrin en yüksek yapılarından sayılan Saat Kulesi /Tepsi Minere bulunur.

Ermeniler'in Karin (Garin), Bizanshlar'ın Theodosiopolis ${ }^{4}$ İslâm mủelliflerinin " Kalıkala "şehri olarak andıkları Erzurum hakkında X. Asır İslâm coğrafyacıları bize az çok bilgi vermişler ve doğuda ev eşyasının en mühimi sayılan kalı (halı ) nın burada yapıldığını ve adını bu şehirden almış olduğunu söylemişlerdir. ${ }^{5}$ Filhakika, ermeni ve rumların bu şehirde hiçbir zaman Kalıkala dememiş olduklarını ve bu şehrin müstahkem bir kalesi bulundugunu ve her taraftan gelen gazilerin burayı nöbetle muhafaza ettiklerini yazarlar. ${ }^{6}$

Tarihin ilk çağlarında Iskitlerin, Hititlerin ve Ortaçağ' nn başında Hazar Türkleri'nin ve LX. yüzyıldan sonra Oğuz Türklerin Erzurum ve civarında akın suretiyle kâh yerleşip kaldıkları veyahut da bir müddet için yerlerini başka yabancı uluslara terkettikleri kaynakların verdiği bilgilerden anlaşılmaktadır.

Hz. Osman (644-646) zamanında 645 yilında Müslümanlar Erzurum'u savaşla almışlardır. Böylece Erzurum ilk defa Arap hakimiyetinde yeni bir çehreye sahip olmuştur. ${ }^{8}$ Şehir " İslâmlar tarafından fethedildiginden beri, ahalisi daima duişmanlarına karşı koydular şehirlerini korudular. Ancak H.133(750) de, Rûm Kayseri şehrı kuşattıktan sonra şehir, Rumların eline geçmiştir. Kayser şehiri yıkmış ahalisini Mezopotamya'ya sürmüştur."

${ }^{3}$ Besim Darkot, a.g.e, s.342.

4 Bizanslılar, elierindekj "Armenya "topraklarını iyi koruyabilmek için Doğu ordusu kumandanı Anatoliyus idaresinde, şimdiki Erzurum Kalesi'ni 415-422 arasında çok müstahkem bir şekilde yaparak garnizon merkezi yaptılar. Anatoliyus, bu müstahkem şehri, genç Kayser II. Teodosiyus'un adıyla "Teodosiyo-Polis (. Teodos Şehri ) adını verdi. ( M.H.Yinanç, "Erzurum" Mad., İA, IV,345).

5 Belazurî̀"Erzurum emiri olan kocası blünce, onun yerine karısı emir oldu. Onun adı Kâli idi. Bu kadın, Kâlıkâla şehrini yaptırdı ve bu şehre Kalıkâle adını verdi. Bunun mânası: Kali'nin ihsanı, hediyesi demektir. Bu kadın, şehrin kapılarından birisi tizerine resmini yaptırdı. Araplar bu kelimeyi Araplaştırarak Kâlikala demişlerdir." diyor ( El-Belazuri, Fütahu'] Büldân, Cev.Mustafa Fayda, Ankaral 987, s,282).

"M.H.Yinanç "Erzurum" Mad, LA.IV, 347.

7 A.Şerif Beygü, ErzurumTarihi, Anttları, Kitabeleri, İstanbul 1936.s.36.

8 Enver Konukçu Selçuklulardan Cumhuriyete Erzurum, Ankara 1992, s.3.

9 El-Belazurî ,Fütâhu'1 Billdân s.321. 
Kaynaklarda 755 de Roma (Bizans ) kıralı Constantına'nın zapt ile harebe olarak bıraktı̆̆ ${ }^{10} 756$ da Halife Ebû Cafer 'in (754-775) kalesini tamir ve tahkim ettigi, 818 de İmparator Theophilius'un surlarını tahribatla yıktığı, 840 da depremle surlarından 18 kulenin yıkıldığı ${ }^{11}$ akabinde Halife al-Mu'tasım'ın (833-842) bluyük masraflarla(500 bin dirhem harcayarak) tâmir ettirdiği, ${ }^{12} 928$ lerde İslam Arap devletinin kuzeyde en uç karakollarının teşkil edildiği ${ }^{13} 949$ da İslâmların elinden çıkmasıyla, Bizanslılar'ın tekrar surlarını yıktığı Kalıkale; X. asırda Bizans imparatorluğunun temlerinden birinin merkezi olmuş ve doğudan gelecek İslâm akınlarına karșı yeniden tahkim edilmiștir. ${ }^{14}$

949 a deģin 300 yıl süren Müslüman Emirliğinin merkezi iken, o tarihten beri Bizashllar'ın elinde yeni tahkimatla daha çok kuvvetlendirmişti.

Bizans İmparatoru II. Basileos (Basil ) 1021 de Doğu'da görulmeden ơnce 1018 "Nikomit Hükümdarı " denilen birisini Erzurum'a gơndermiştir. Bu zat büyük bir ordu toplayarak, kendileri için çok gerekli olan Teodosiopolis (Erzurum) şehrini yeniden inşâyâ başlamıștır ${ }^{15}$.

\section{Selçuklu Akınları :}

Oguzların Kınık boyundan olan Selçuklular; İslâm ve Bizans tarih yazarlarına göre 1048 ve Ermeni müverrihlerine nazaran 1049 senesinde Erzen-i Rum (Erzurum) şehrini zapt ve tahrip etmişlerdir.

Sultan Tugrul Bey'in (1037-1063) emri ile Bizans İmparatorluğu'nu istilâya memur olan İbrahim Yinal gazâ için Bizans'ın doğu sınırını geçerek Erzenu'r Rum'a kadar geldi. ${ }^{16}$ Çokluklarından dolayı Theodosiopolis (Erzen) surlarının içine sı̊̆ınmaya lüzum görmeyen şehir ahalisi, Türk ordusu ile mücadeleye hazırlanmışlardı. Fakat şehrin dışında bir gün devam eden bu muharebelerden sonra, bozulup şehrin içine kaçmışlar ve burada mücadeleye 6 gün devam etmişlerdir. İbrahim Yinal savaşın uzun sürdügŭunü görünce, evleri ateşlemek için mancınıklarla yağlı paçavralar atturmıştır. Rüzgâr tesiriyle büyük bir yangın çıkmış ve şehir büsbittün yanmıştır. ${ }^{17}$

Aynı olayı Urfalı Matheos da şu şekilde anlatmaktadır:

"Artzın (Erzen) denilen çok kalabalık ve meşhur ermeni şehrine geldiler. Türkler, Artzın'ı sursuz vaziyette lâkin sayısız erkek ve kadın, hesapsız altın ve

\footnotetext{
${ }^{10}$ Bar Harbraeus, Ebô'l Faraç Tarihi, C.1 (Trc: Ö.Ruza Doğru ) Ankara 1987, s.199.

${ }^{11}$ Bar Harbraeus, Eba'l Faraç Tarihi, C.1 s.29.

${ }^{12}$ El-Belazurî, Fütûbu'l- Bủldân, s.286.

${ }^{13}$ E Honigmann, Bizans Devletinin Doğu Sının (Trc: Fikret Işıltan ) Istanbul 1970, s.40.

${ }^{14}$ M.H. Yinanç "Erzurum" Mad., IA.s. 347-348

${ }^{15}$ Georg Ostrogorsky, Bizans Devleti Tarihi, (Trc:Fikret Işıltan) İstanbul 1991,s.291-292; E. Honigmann, Bizans Devletinin Dogu Sınırı, s.161.

${ }^{16}$ İbn'ül Esir, El-Kâmil Fi’t Tarih .C.IX ( Trc: A Özaydın, A. Ağırakça )İstanbul 1987. s.415.

${ }^{17}$ M.H.Yinanç ."Erzurum" Mad, ,AI, IV, 348.
} 
gümưş ile dolu buldular. Şehir halkı Müsluman askerleri görunce, hep birlikte onlara karşı geldiler. Artzın çevresinde şiddetli bir çarpışma oldu. Mücadele butiun gün devam etti. Tarlalar kanla boyandı. Zira ne bir sığınılacak yer, ne de yardım ümidi vardı. Artzınlar kuruluş çaresi olarak önlerinde sadece ölumü görüyorlardı. Şehrin savunucuları, sonunda Müslümanların çokluğu altında, ezilerek firara mecbur kaldılar. Ellerinde yalınkılıçları ile kaçanları takiben Artzın'a giren (Selçuklular) çok sayıda insanı öldürttuler. Ele geçirilen altını, gumuüşü ve kıymetli kumaşları söylemeye gerek yoktur. Çünku bunların miktarmı kalem ile ifade etmek imkân haricindedir. Herkesin bu arada sık sık Davtug/ David denilen korepiskoposun hazinesi ve evinden 800 altınlık ökuz yükü çıkıordu. Buna dair haberi ben şahsen duydum. Artzın'da baş âyin icra edilen 800 kilise vardır. İşte güzel ve muhteşem Artzın şehri acımasız yok etme ve ölüm ile mahvolmuştur. Toprağa gömülmeyip, hayvanlara yem olan ileri gelenlerin ve din adamlarının kaybı ... Kadınlar ve çocuklar da birlikte esir olarak İran'a götürulduler “. " ${ }^{18}$ Selçuklular, Artze galibiyetinden sonra Basenan/Pasin Ovası'na geçerek 18 Eylül 1049 da Hasankale (Kapetru) Savaşını zafere dönusşüreceklerdir.

Bu yıkımdan sonra bir daha Erzen/Arzen şehri şenlenmedi. Sağ kalabilen ahâlisi Karın ( Kalıkala /Theodosiopolis: Erzurum) şehrine çekilip yerleştiler. Bundan sonra, her halde ovada ve Erzurum'a göre kışlak sayıldığından veya kuzeyde bulundugundan ${ }^{19}$ veya yanıkhı̋̆ından dolayı ve toprag̊ı karamsı olmasından dolayı ${ }^{20}$ yıkık Arzen /Artzın şehrine Oğuzlar "Kara-Arzen/Arz" adını verdiklerinden, bugiin buradaki köye " Karas/Karaz/Kara-Arz" denilmektedir.

Arzenliler Karin/Karun/Theodosiopolis şehrine yerleşmesiyle, bu tarihten itibaren buraya da " Arzen "adı verilip, Rumların elinde bulunduğu için ve Müslumanlar idaresinde Siirt bölgesindeki Erzen'den ayırdedilmek uzere buraya İslâm eserlerinde ve paralarda "Erze-Rum". "Erzen Rûm", Erzen-ir Rûm "manâsına Erzurum denilmiş, yazılmış ve öyle tanınmıştır. ${ }^{21}$

Azimîye göre:h.439 (1047/1048) da Türklerin fethettikleri ${ }^{22}$ Erzurum Kalesi'nin, burçlarının metinliği ile alınmaz serhat şehri haline gelmiştir. Bu sebeple XI. asrın ve hatta batısındaki şehirlerin ve kalelerin ekserisi Türkler tarafindan fethedildiği halde Erzurum, uzun munddet Bizans hâkimiyeti altında kalmıştır.

Bizanslıların doğu başbuğu Anatoliyus tarafindan Sasanlılar'ın karşı bir ordugâh şehri ve hudut kumandanlığı merkezi olarak 415-422 arasında sekiz yl çalışllarak kale ve surların çok sağlamca yapılıp "İkinci " ve "Genç" lâkaphı Kayser Todosiyos'un adıyla buraya rumca "Teodosiyopolis (Teodosiyos- Şehri)adı

\footnotetext{
${ }^{18}$ Urfalı Matheos. Vekayınâme, (Trc: Hrant D. Andreasyan ) Ankara 1987.s. 86.

${ }^{19}$ M.F.K.rzioglu, Kars Tarihi , C.1. İstanbul 1953. s.322.

${ }^{20}$ I.Hakkı Konyalı, Abideleri ve Kitabeleri ile Erzurum, Istanbul 1960. 103.

${ }^{21}$ Şemseddin Sami, Kâmus'ül -Alâm,C. II, Istanbul 1306.s. 829, M.H.Yinanç̣ "Erzarum" Mad. İ, IV, 348; Afif Erzen, Streck, "Erzen" Mad., IA, IV, s. 337-338.

${ }^{22}$ Azimî, Azimi Tarihi (Yay:Ali Sevim ). Ankara, 1985, s.8.
} 
verildiğine yukarıda işaret edilmişti Yine ilk İslam fetihleri sırasında, dünyaca meşhur olan en iyi Türkmen kal//halılarının en iyi cinsinin dokunduğu yer oldugundan Kal1- Kal(k) (:Kalı/Hal1- Şehri) diye tanındığına degindiğimiz bu müstahkem şehir 949'a değin 300 yıl Müslüman emûrliğinin merkezi iken, o tarihten beri Bizanslılann elinde yeni tahkimatla daha çok kuvvetlenmiştir. $\mathrm{Bu}$ yüzde, kuşatması uzun sürecek olan Erzurum/Arzenrum şehrini ada gibi ortada koyup burayla uğraşmayı sonraya bırakan Selçuklular, Pasin ve Erzurum ovalarına hâkim olmuşlar, 1071 Malazgirt Zaferi'nden sonra ele geçinceye değin burası, Rumların dayandığı buyuuk askeri şehir ve hareket üssü ve vazifesinin görmüştür. ${ }^{23}$

İbrahim Yinal'den sonra Büyük Selçuklu Sultanı Tuğrul Bey, Bizans'1 istilâya karar vererek 1054 yazında Anadolu'ya ayak bastı.

Tuğrul Bey, Bizanslılar đzzerine sefer edeceğinden; kale kuşatmağa ve döğmeye yarayacak arabalar, filler, mengeneler ve mancılıklarla ilerleyip Bargiri (Muradiye ), Arceş (Erciş)'i alıp Pasinlerden ve Avnik Kalesi önünden geçerek Erzurum'u kuşbakışı gören bir tepeye gelmiş, şehrin kalesini uzun uzun seyir ve temaşa ettikten sonra, bu metin kalenin zaptının uzun zaman alacağı dủşlincesiyle, buranın muhasarasından vazgeçmiş ve Malazgirt'i almaya gitmiştir. ${ }^{24}$

İbn'ül Esir, h. 446 (1054) yılına ait kaydında Selçuklu akınına temas ile "Tuğrul Bey, Anadolu gazâsı surasında, Erzen-er Rum'a geldi". ${ }^{25}$ diğer bir müellif Bar Herbraus da "Erzen er-Rum memleketini aldı. Burası bu ana kadar Romalıların (Bizans ) elinde idi." "26 diye yazmaktadırlar.

Sultan Alp Arslan ve Sultan Melikşah zamanlarında, ne bizzat kendilerinin ve ne de Anadolu içlerine gazâlarda ve fetihlerde bulunan ùmerâsının burayı muhasara ve fetih teşebbüsünde bulunduklarına dair bir kayda rastlamıyoruz.

Türkler, Anadolu'da birçok şehirleri ve kaleleri hatta Erzurum Kalesi'ne nazaran ikinci derecede ehemmiyete haiz kasaba ve kaleleri birer birer fethettileri halde Erzurum'a uğramamışlardir. Erzurum, âdeta uzaktan mahsur bir hale getirilmek istenmiş, kendi kendine düşmesi için icâb eden bütün tedbirler alınmıștır.

Bizans imparatoru Romanos Diogenes (Romen Diyojen) 1071 de Sultan Alp Arslan'la karşılaşmak üzere Malazgirt'e giderken Erzurum'a uğramıştır. ${ }^{27}$

1071 den 1080 e kadar Erzurum Kalesi gene Bizanslılar'ın elinde kalmış, ancak 1080 senesinde güzel Erzurum, Melikşah'ın kumandanlarından Emir Ahmed tarafindan fethedilerek, bu havalideki hurıstiyan hâkimiyetine kat'i suretle nihayet

\footnotetext{
${ }^{23}$ M.H.Yinanç,"Erzurum" Mad., İA,IV,348.

${ }^{24}$ M.H.Yinanç, a.g.e. aynı yer.

${ }^{25}$ İbn'ül Esir, El Kâmil Fi't Tarih, C.IX,s.454-455.

${ }^{26}$ Bar Herbraus, Ebü'l Faraç Tarihi ,C. I.s.306.

${ }^{27}$ M.H.Y Yinaņ,,"Erzurum" Mad., IA, IV, s.348; F.Sümer; Ali Sevim, İslam Kaynaklarına Göre Malazgirt Savaşı, Ankara 1988, s.51.
} 
verilmiştir. ${ }^{28}$ Demek ki Erzurum Kalesi'nde Selçuklular'ın imar ve tahkim payı vardır. ${ }^{29}$ Bundan sonra Türkler, Erzurum ve havalisine geniş miktarda ve mikyasta yerleşmişler ve serpilmişlerdir.

Selçuklular Erzurum Kalesi'ne çok ehemmiyet vermişler ve burayı daimi suretle emniyet altında bulundurmak için Trabzon Bizanslılarına karşı Bayburt'u; Gürcüler'e karşı da Micingert, Avnik, Zivin Kalelerini çok sağlam bir surette yaptıkları duş̧ünülürse, Erzurum Kalesi'nin ne kadar üstün olduguna şuphe yoktur. ${ }^{30}$ Fakat, Rusların 1829 daki sebebiyle günümüze kadar hiçbir kitabesi kalmamıştır.

\section{Saltuklu Çă̆ı}

Merkezi Erzurum olan Saltukoğulları emâretinin kuruyucusu olan Emir Saltuk'un dedesi Ebû'ull Kasım'in 1080 senesinden itibaren bu emareti kurmuş oldugu anlaşılmaktadır. ${ }^{3 t}$

Saltukoğulları, Erzurum Kalesi'ni (mahv ve isbat) yolu ile imar ve tamir etmişlerdir. Bugün ayakta kalan kalenin mühim kısmı Saltukoğullarınındır. ${ }^{32}$ Kaledeki Saat Kulesi /Tepsi Mimare de onlardan kalmalıdır.

Bu beyliğin hâkimiyet süresi 134 yll sürmủştưr. ${ }^{33} \mathrm{Bu}$ emâretin dördüncü emiri İzz ed-Din (1132-1168) zamanında ve altıncı emiri Nasr ed- Din Muhammed (1168-1191) zamanlarında Gürcistan kraliçesi Tamara, Erzurum'a ordu göndermiş ise de kale önunde iki savaş verdikten sonra Gürcüler muhasara cesaret edemeyerek geri dönmusslerdir.

İbn'ül Esir İzz ed-Din zamanundaki savaş1 1153 yllında göstererek, "Armeniadaki Gürcủlerie Erzen ür-Rum hâkimi Salık (Saltuk) arasında bu yıl çetin savaşlar oldu. Gürculer onu esir aldılar. Fakat daha sonra salıverdiler."demektir. ${ }^{34}$

Yine aynı emir zamanında 1161 yllnda İbn'ül Esir'in ifadesiyle "Gurcülerle Erzene'r-Rum hâkimi Saltuk b. Ali arasında savaş ve çarpışmalar oldu. Sonunda Saltuk ve askerleri yenildi. Saltuk esir dủştio", ${ }^{35}$ Bilâhare Ahlat hâkimi eniştesi Şah-ı Ermen' in tavassutuyla serbest bırakıldı. 1168 de İzz ed-Din Saltuk'un veziri Firûz, Kars ve Bardız Kaleleri'ni tamir ettirmişti.

İzz ed -Din 'in oğlu Nasır ed-Din Muhammed de Gürcỉ tehlikesi ile karşı karşıya kaldı. Gürcúler cüretkâr bir hareket ile Erzurum kalesi önlerine kadar geldiler. Mơteakiben kaleyi kuşatma hazırlığına giriştiler. Nasır ed-Din Muhammed

\footnotetext{
${ }^{28}$ M.H.Yinanç, "Erzurum” Mad. IA.IV, s.349.

${ }^{29}$ I.Hakkı Konyal, Abideleri ve Kitabeleri ile Erzurum, s. 104.

${ }^{30}$ A.Şerif Beygü, Erzurum Tarihi, Anıtları, Kitabeleri, Istanbul 1936, s.26.

${ }^{31}$ M.H.Yinanc "Erzurum" Mad., IA, IV, s,349

${ }^{32}$ I.Hakkı Konyalı, Abideleri ve Kitabeleri ile Erzurum, s.104.

${ }^{33}$ Saltuklular' in 1202 den sonra bir kolu bir süre Micingerd'de devam etmiştir.

${ }^{34}$ İbn' all Esir, El Kâmil Fi't Tarih C.XI,164.

${ }^{35}$ Ibn' ưl Esir, El Kâmil Fi’t Tarih,C.XI. s. 329-330.
} 
ve iki oglu, ortalık ağardıktan, glineş doğduktan sonra Erzurum dışına çıktılar. Yaya ve atlılar ile Gürculere saldırdılar. Akşama kadar devam eden vuruşmadan sonra netice elde edemeyince Saltuklu cengâverleri kaleye döndüler, Şehir halkı kaleden olup bitenleri görmüş, "bu felâket bize nereden geldi. Memleketimizde hiç bir zaman hıristiyan görmemiştik" demişlerdir. Sabah olunca davul ve boru sesleri duyuldu. Kaledekiler de harekete geçtiler Herkes sur kapilarında toplanmaya başladı. Gürcullere karşı da şiddetle savunma yapıldı. Sonunda Gürcủ komutanı David geri çekildi. ${ }^{36}$

Erzurum ve yöresindeki Bizanslılardan intikal eden kaleleri tahkim eden Saltuklulardan Erzurum'da kalan en önemli eser Saat Kulesi/Tepsi Minare'dir.

1202 de Saltuklular' in ulkesi Anadolu Selçuklularına ilhak edildi.

1196 da Konya Selçuklu tahtına oturun Rukkn ed-Din Süleyman Şah II, 1202 de Erzurum'a gitti. Buranın emiri el-Melik ibn Muhammed b. Saltuk'un oglu Rükn ed-Din'i karşılamaya çıtı ise de Rükn ed-Din, onu yakalayıp hapse attı; ve şehri aldı. Bu zat Erzurum'daki bu hanedanın son hâkimiydi. ${ }^{37}$

Bu şekilde Saltuklular'in yikılmasından sonra durumdan faydalanan Günculer'in harekete gecip tehlike arz etmeleriyle Rukn ed-Din onlara gereken dersi vermek için Erzurum'dan hareketle Micingert Kalesi yakınındaki savaşı yapacaktır.

Böylece Türklerin Erzurum'da temelli olarak yerleşmesi 1071 de Selçuklu Imparatoru Alp Arslan' in Malazgirt'te Bizans İmparatoru Diyojen ile yaptığı büyük savaşta başlamış ve Saltuklu hâkimiyeti tesis edilmiştir.

Saltuklu hâkimiyeti 1202 yılına kadar devam etmiştir.

Saltuklular Erzurum Kalesi'nin tahkim ve tamiri ile beraber günumüze kadar gelen önemli eserler bırakmışlardır. Erzurum'dan başka Oltu, Bayburt, Ispir,Tercan, Tortum, Micingert, Avnik, Zivin, Bardız, Kars Kaleleri onların eleyle revizyondan geçmiştir. Adı geçen kaleleri özellikle Gürcułler'e karşı tahkim etmişlerdir.

Saltuklular'ın yıkılmasıyla, Erzurum Selçukluları dönemi başlamıştır. (1202-1230).

Rükn ed-Din Süleyman, Erzurum'u kardeşi Mugis ed-Din Tugrul Şah'a verdikten sonra, Micingert savaşında yenildiğinden bu acı ile hemen Konya'ya döndü, biraz sonra da kederinden olldü.

Mugis ed-Din Tuğrul Şah'in ilk işi Pasinlerden Gürcüler'i çıkararak Saltuk'un yaptırmış olduğu Hasankale, Avnik, Zivin, Micingert kalelerini yeni baştan tamir ederek içlerine kâfi miktarda asker yerleştirdikten sonra, o sırada

\footnotetext{
${ }^{36}$ M.Brosset, Histoire de la Georgie", I, St. Petersburg 1849; s.432, M.H.Yinanç, "Erzurum" Mad., IA,IV,349.

${ }^{37}$ İbn ull-Esir, El Kâmil Fi’t Tarih XII,146-147; Bar Herbreaus Ebü'l Faraç, C.Il,s.474.
} 
Erzurum'u kuzeyden tehdit eden Trabzon Rum kurallarına karşı müstahkem bir mevki haline getirdiği Erzurum ve Bayburt Kalelerini yeni baştan çok esaslı ve metin bir surette yaptırdı.

Mugis ed-Din Tuğnul(1202-1225), merkezi emâreti olan Erzurum'u metin surlarla tahkim etmiş, şehrin içerisin e lâik ve dini mebâni ile süsulenmişse de zamanla, harpler dolayısıyla bunlar harap olarak bugün ortadan kalkmıștr. ${ }^{38}$

Erzurum Kalesi'ne birçok ilaveler yaptı̆̆ı, harap yerlerini tamir ve tecdit ettiği muhakkak olan fakat, kitasbeleri bize kadar gelmediği için nereleri, hangi senelerde yapıldığını bilemediğimiz ${ }^{39}$ Mugis ed-Din Tuğrul 1225 de ölünce yerine oğlu Rükn ed-Din Cihan Şah (1225-1230) geçmiş ve Anadolu Selçuklu hükümdarı amcası Alâ-ed-Din Keykubat( 1220-1237)' ın niyetinden șiluphelenerek Celâl ed-Din Harzemşah ile işbirliği yapmış ve Yassıçemen'de onun mahiyetinde bulunmuş̧ur. Amcası lehine savaşı kaybedince de Alâ-ed Din Keykubat'ın huzuruna çıkarılmış̧ı. Alâ-ed-Din Keykubat, onu alıp Erzurum'a gitmiş ve şehir hâkimi olan kişi bu ş̧ehri etrafindaki kalelerle, içinde hazinelerle birlikte Alâ-ed-Din Keykubat'a teslim etmişti. $^{40}$

İbni Bibi'ye göre "Alâ-ed -Din Keykubat, Erzurum'a doğru gelirken yolda bir haber işitti ki Erzurum'da bulunan ümerâ şehri müdafa edeceklermiş. Bâhusus Yassıçemen'de bozulan bir kısım Harzem askeri Erzurum'a kaçtığından burasını muharebesiz teslim etmek istemiyordu. Öteden beri müstahkem bir şehir olan Erzurum, son hadiseler üzerine bir kat daha tahkim edilmiști. Öyle ki gerek Harzem kumandanları ve gerek Rukn ed-Din 'in şehirde bulunan askerleri ş̧ehrin kale ve surlarına son derece gliveniyorlardı. Bunun üzerine bir elçi göndererek Erzurum'un teslim edilmesi, aksi halde şehre karşı şiddet kullanılacaşı bildirildi. Erzurum'lular gerekli görüşmeden sonra şehre teslim edeceklerini bildirdiler. Bunun üzerine Sultan Alâ-ed-Din Keykubat, yanında Rükn ed-Din Cihan Şah ve diğer maiyeti olduğu halde büyuk bir ordu ile Erzurum Ovası'na indiler. Sonra Erzurum Kale ve surlarına Selçuk askerleri yaklaştı. Askerlerin mızrakları sanki güneşin yüzünü kapıyordu. Nasıl ki yırtıcı kuşların kanatları gökyüzünde güneşe hail olursa bu askerlerin mızrak ve süngüleri de samâya öyle yưkselmişti.

Sehrin kale ve surlarında askerler, Sultan'ın bu heybetli ordusu karşısında heykel gibi kaldılar. Müdafaa takatleri kalmadı. Bu korkunç kale surları, sanki göz açıp yummada sükût etti. Büyuik bir heyacan, sürurla kale kapılarından şehre akın eden Selçuk askerleri, duvar diplerinde, kale bedenlerinde rastgeldikleri askerleri öldürdüler. “

\footnotetext{
${ }^{38}$ A.Șerif Baygü, Erzurum, Tarihi, Anıtları, Kitabeleri, s.47.

${ }^{39}$ I. Hakk1 Konyall, Abideleri ve Kitabeleri ile Erzurum, s. 104.

${ }^{40}$ İbn'ul Esir, El Kâmil Fi't Tarih, c. XII, s.454.
} 
İbni Bibi şehri tasvir ederek derki: "Şehrin etrafinı çeviren dağlar süreyya yıldızı gibiydi. Erzurum şehri Keşkeşan, Benatünna'ş yıldızları gibi bu süreyya yıldızının elinden tutmuş vaziyetini gösteriyordu.

Şehir halkı bu muzaffer ordusunu kahır ve gazâbından korktukları için feryâd ư figânları sanki âsumânâ doğru yükseliyordu. Şehrin müdafileri Selçuk askerleri karşısında atılmış bir pamuk gibi oldular. Pek azı kılıçtan kurtuldu. Şehrin ortasında yưkselen kalenin, yüksek kulesi (bugünkü Saat Kulesi ) üzerinde güneş ay şekli olan Selçuklu bayrağı dalgalanıyordu. Butün hisar kulelerinde bu bayraklar çekilmişti. (Nihayet) Sultan İç-Kale'ye girdi. Bir müddet istirahatten sonra, Rükn ed-Din Cihan Şah'ın ve babasının sakladığı hazineleri meydana çıkartarak, hazinesine katt1.

Şehir ahalisi akın akın huzuruna gelerek Sultan'a sadakat ve kulluklarını arz ettiler. Sultan, büttin geçmiş vukûatları affetti. Esir yeğenini affederek Aksaray'a gönderdi. Sultan Erzurum ve Civarındaki beş kaleyi de aldı. Erzurum'a vali ve kumandan olarak gönderdiği liyâkatıyle ş̋̆hret olan Emîr Mübariz ìd-Din Cavlı ta'yin edildi. ${ }^{41}$

Bu suretle Sưleyman Şah tarafindan 1202 senesinde fethedilip kardeşi Tuğrul Şah'a verilen Saltuk-ili Erzurum, onun ve oğlu Cihan Şah'ın elinde 28 kaldıktan sonra bir daha ayrılmamak üzere 1230 senesinde Selçuklu ülkesine katıldı. Bu zamanda Saltuk-ili'nin 35 kalesi oldugu rivayet edilir. ${ }^{42}$

1080-1242 yılları arasında 162 yıl kadar minhasıran Türk hakimiyeti altında kalan serhat şehri Erzurum, tarihinin en saâdetli ve en bahtlı yıllarını yaşamış, hem mamur ve hem de zengin olmuştur. Burası Anadolu'nun en zengin, en büytuk şehirlerinden sayılıyordu. ${ }^{43}$

1237 da Alâ-ed-Din Keykubat zehirlenerek oldukten sonra yerine oğlu II. Glyaseddin Keyhüsrev geçti.

Bu sırada Erzurum valisi olan Sinan ed-Din Yakut, Trabzon Rumlariyla başarıh harpler yaparak, onlan Erzurum hududuna yaklaştırmıyordu.

Birtakım siyasi ve diplomatik hadiselerin oluşumuyla, Moğolların Selçuklular aleyhine dónmesi sebebiyle Çarmağan Noyan'ın, Baycu Noyan Kumandasında gönderdigi kuvvetler 1242 senesinin kışında Erzurum'u muharasara ettiler. Alâ ed-Din Keykubat tarafindan tahkim edilen Erzurum sûrlan bu korkunç düşmana karşı mukavemet edecek bir kudrete haizdi. ${ }^{44}$

${ }^{41}$ İbni Bibi, El-Evâmirì'l- Ala'iyye,Fi'l-Umuri'l-Ala'iyye, (Haz: Adnan Erzi), Ankara 1956, s.403,406,409,416.

${ }^{42}$ Osman Turan Selçuklular Zamanında Türkiye, İstanbul 1971, s.374.

${ }^{43}$ M.H.Yinanç, "Erzurum" Mad. İA,IV, s.349.

${ }^{44}$ A.Şerif Beygü, Erzurum, Tarihi, Antları, Kitabeleri, s.65. 
Bar Hebraeus, 1240 yılına ait kaydında "Tatarlar geldiler, İberyalıların (Gurcülerin) memleketinden Erzen er-Rum hududuna kadar uzanan sahaları yağma ettiler" $^{\text {"45 }}$ diye yazmakta ve bu istilanın Carmagan (Cirmagun) Noyan tarafindan idare edildigini ifade etmektedir.

1239 da Gürcistan'1 işgal, Kars ve Ani beldelerini zapt eden Mogolların kumandanı Carmagan (Cormagun / Curmagun) Noyan yerine 1242 de Baycu Noyan ta'yin edilince Gürcü ve Ermenilerin de dahil bulunduğu Moğol ordusu 1242 sonbaharında hareket geçerek Erzurum önlerine gelmekte iken, kale kumandanı Yakut da şehirde savunma hazırlıklarını tamamlamaya çalışıyordu.

Türkistan ve Türkiye kervan ve ticaret yolu üzerinde bulunan Erzurum, "ana beldelerden" sayılıyor, zenginliği ve Anadolu'nun kapısı olmakla her zaman chemmiyetini muhafaza ediyordu.

Baycu Noyan, Erzurum'a varınca surlara karşı mancınık ve arrade (balistik makine)leri kurdurdu.

Mogollardan korkan ahali acınacak durumda batıya doğru kaçıyor ve firsatını bulabilenler de kaleye iltica ediyordu. Baycu Noyan, Selçuklular'ın teslim olmayacağını görünce, hemen muhasaraya koyuldu. Baycu, arradeleri ile Erzurum surlarını döğmeye, gedikler açmaya çalışıyordu.

Muhasara ve savaşlar şiddetli cereyan ediyor; Türklerin kahramanlığ ve kış basması karşısında Moğolların cesareti kırılıyor; hatta dönmek niyetinde oldukları gözüküyordu. Şehrin sü-başısı Sinan ed-Din Yakut, istediği yardım kuvvetlerini bekliyordu. Bu bekleyişten dogan ümit de onların mukavemetini artırıyordu. Zira Babai isyanı dolayısı ile Erzurum ordusunun merkeze çağrılması bu üssün zayıflamasına yol açmış ve henuz gereken miktarda askerin orada toplamasına imkan vermemişti. Baycu Noyan, Moğolların yenilmezliłine güveniyor, ama muhasaranın uzamasına da kızıyordu. Şehrin teslim olmasını teklif etti ise de; red cevabı alınca daha şiddetli hücumlara giriștirler.

Baycu Noyan kumandasındaki Moğol askerleri şehrin surları karşısında tas yığdurarak büyük on iki mancınık ve arrade aletleriyle gece ve gündüz şehri taş yağmuru altına aldılar. ${ }^{46}$

Şehrin başkumandanı Sinan ed-Din Yakut ile diger hıristiyan kumandan Ístankos; Türk ve hıristiyan askerleriyle şehrin surlarını, kulelerini cansiperane bir surete müdafaa ediyor, olağanüstu bir gayret ile surlar hemen tamir ediliyor ve Mogolların girmesine izin verilmiyordu. Bu kanlı boguşmalarda taraflardan epeyce zayiat oldu. Geceli gündüzlü devam eden ve çok sayıda insanın ölümüne sebep olan muhasara, içeriden ihanet sonunda Mogolların lehine gelişme arzetti. Baycu Noyan Selçuklu yardım kuvvetleri Erzincan'a vardığı sırada Erzurum'a girdi.

${ }^{45}$ Bar Hebraeus,Ebu'l Faraç Tarihi,c.II, (Cev.Ö.Riza Doğrul) Ankara 1950, s.539.

${ }^{46}$ Aynî, İkd el- Veliyiddin Efendi no:291 (XIX,) s.263-264. 
İbni Bibi'ye göre Şehrin bir taraf sur ve kulesini müdafaa eden Erzurum şahnesi (valisi ) olan Divrinli Şeref ed-Din , Sinan ed-Din Yakut ile arası açık olduğu ve kin beslediği için fırsatı ganimet bilerek; Yakut'dan intikam almaya karar verdi. Bir gece gizlice Baycu Noyan 'a haber göndedrerek, "Eger benimle akrabalarımın hayatına dokunmazsan müdafaa ettigim kaleyi teslim ederim"teklifi ile Baycu'dan bir talimat aldıktan bonra savundugu burç üzerine Moğol ordusunun içeri akmasını sağladı.

Bu teklifi memnuniyetle karşılayan Baycu Noyan, iki yü seçme askerini karanlık bir gecede teslimi vaad edilen kuleye gönderdi. Bu askerler merdiven ile burcun üstüne çıktılar. Kuleyi müdafaa eden askerleri öldürdüler. Kulenin kapı, pencerelerini kırarak içeriye girdiler. Buradan şehre inerek mudhiş bir süratle yağma ve kıtale başladılar. Hıyanet haberi alan Yakut, derhal kuvvetlerini toplayarak çetin savaşlara girişti. Diğer burçları müdafaa edenler de mevkiilerini terk ederek savuştular. Bu mücalede hem Mogollardan hem de Selçuklulardan epeyce insan hayatını kaybetti. Birçok beyler de şehid oldu. Moğollar her taraftan şehre girdiler, rastgeldeklerini kılıçtan geçirdiler. Şehrin üstỉne Mogollar Belâ bayrağını çekerek, şehrin kadınlarını esir ettiler. Çocukların başlarını keserek, kelleleri yere yuvarlandı. Bunların elinden her hangi yaşta olursa olsun hiç bir insan kurtulmadı. Şehrin her tarafı yağma edildi. Bu felaket, bu facianın korkunç saatlerinde, semaya yükselen âh ve feryat karşısında sanki güneş, ay küsûf ve husûfa uğradı. Mogollar hiç merhamet göstermediler. Şehrin her tarafı ceset yığınları ile doldu.

Sonra şehrin bedbaht kumandanı Sinâneddin Yakut'u konağından çıkardılar, başı açık, küçuk oğlunun elinden tutmuş idi. Böylece Baycu Noyan'ın huzuruna çıkardılar. Saraydaki kıymetli altın, gümüş ve daha nice eşyalarını kumandana getirdiler. Baycu, bu kadar gümuss paraların çokluğuna hayret ederek Sinan ed-Din'e dedi ki: "Niçin bu gümüş paralarla gününü kara ettin. ? Bunu ne için askerlerine dağıtmadın? Ve neden tasarruf ettin? Sinan ed-Din: "Bu paralar sana kısmet imiş " cevabını verdi. Bunların ikisini de öldïrdu. ${ }^{47}$ Bundan sonra.,Erzurum yakıld. Surların yerle bir edildi.

Böylece Erzurum, Moğol istilâsının ilk kurban oldu. Mogollar Türkiye'nin istilâ kapısını artık açmışlardır.

Erzurum'un kanlı bir suretle sukutu bütün Selçuklu sınırlarında müthiş bir sarsıntısı meydana getirdi. İbni Bibi'ye göre: "kafasında tam bir perişanlık" beliren Gıyas ed-Din Keyhüsrev, bu felâketi önlemek için Kösedağ"da, Moğollar"la yapılan bir savaşta (1243) buiyük bir hazimete uğrad.

Devrin tarihçileri Erzurum yağmasına yer ayırmışlardır ve acılı satırlar ile olayı ebedileştirmişlerdir. Bunlardan Bar Hebreaus: "Bunlar bir kaç gutn içinde bu müstahkem mevkii zaptederek erkek, kadın bütün âhaliyi kılıçtan geçirdiler ve

${ }^{47}$ İbni Bibi, El-Evâmira'l-Ala'iyye Fi'l- Umâri'l-Ala'iyye, s.514-517. 
yalnız köleliğe elverişli olan genç erkekler ve kızları korudular. Tatalar, Sinan ve genç oğlunu da öldürerek, burasını (Erzurum) harebe halinde burakıp gittiler." ${ }^{, 48}$

Ebûlferec İbnü'l İbrî de 'Erzenu'r-Rum'u kuşatıp zorla burayı elde etti. Ve ahaliden birçok kimseleri kılçtan geçirdi. Çocukları tutsak aldı ve şehrin her tarafını yağma etti. Ve sübaşısı Sinan'ı dahi oldürdü. ",49 demektir.

Genceli Kirakos ise bu konuyla ilgili olarak şöyle yazmaktadır:

"Tatarlar Garin'e varınca, şimdi Garin denilen Theodosiopolis şehrini muhasara altına aldı. Teslim olmaları için ahalı nezdinde göruşme memurları gönderdi. Garinliler bu teklifi kabul etmedikten başka, onları hakaretle kovdular. Surların üstüne çıkarak Tatarlar'a seb ù setm etmege başladılar. Bunlar, sulhperverane tekliflerin reddedildigini görilnce surun yıkılması esbabını ihsar için genarellerinden emir aldilar.

Derhal faaliyete geçerek, birçok mancınık kurdular ve suru yıktılar Kale içine girerek ateşlediler. Burası birçok hıristıyan ahâliden başka, Tacikler ve onlara iltihak eden birçok havali halkı ile doluydu.

Orada büyük-küçük kuvvetlerle sayısız Tevrat ve İncil buldular Düşmanlar pek kıymetli olan kitapları yağmaladılar. Tatar ordusunda hizmet eden hıristiyan askere ucuz fiyatla sattılar. Bunlar o kitapları büyük bir sevinçle aldılar."

Konya Selçuklu Hưkümdarlanı İran Mogolları diye de anılan İlhanlılarla bir antlaşma yaparak Selçuklu Devleti'ni Illhanh himayesine sokmuşlardı. İşte bundan sonra Erzurum şehri yeniden iskân edilmiş ve Anadolu Selçuklu Sultanlığı'nın inkırazına (1308) kadar, bu saltanatın bir vilâyeti olarak kalmış ise de, Mogolların devamh uğrağı olduğu için, her zaman zarar görmüştür. Selçuklu hânedânının saltanattan düşmesinden sonra, Erzurum İlhanl vâlileri tarafindan idâre edilen Rum ülkesine bağlı veilâyetlerden birinin merkezi olarak kalmıştır. ${ }^{51}$

İthanlıların ilk hükümdan (Han) Hülâgü'dưr (1256-1264). O, İran da İthanlı Devletini kurduktan sonra, orduları ile Firat ve Dicle havalisine hücum etti. $\mathrm{Bu}$ meydanda Erzurum'dan Sivas"a kadar akınlarda bulundu. Hülâgü'nün "açtığı hanpler esnasında harap olan şehirler,kısmen kendi saltanatı zamanında yeniden inşâ edilmiştir. "s.52 tefsiriyle Erzurum'u da imâr ettiğini söyleyebiliriz.

Zaten Illhanlılar şehrin ve bu kalenin imârına büyưk ehemmiyet vermişlerdir. Bilhassa Muhammed Ölceytu Han'ın (1304-1317) hâkimiyeti

\footnotetext{
${ }^{48}$ Bar Herbreaus, Ebu'l Faraç Tarihi, c.II, S.541.

${ }^{49}$ Ebù'l Farac İbnü'l İbrî, Tarih-i Muhtasaru'd-Düvel (Çev: Şerafettin Yaltkaya), İstanbul 1941, s. 19.

${ }^{50}$ Eduard Dulaurier, "Ermeni Müverrihlerine Nazaran Moğollar”, Türkiyat Mecmuası İst. 1926. s.117-118.

${ }^{51}$ M.H.Yinanç, "Erzurum" Mad. IA, IV, s.350.

${ }^{52}$ W. Barthold, "Hulagu" Mad., IA.V.s. 581.
} 
zamanında ilân edilen imar seferberliginde şehir cami, mescid, türbe, han, hamam gibi bưyưk ve abidevî eserlerlë súslenmiş, kalesi tahkim edilmiştir.

Avnik Kalesi'nde Ölceytu'nün kitabe parçaları bulunmuştur. Eger Erzurum un kale kitabeleri bize kadar gelseydi bunların arasında muhakkak İlhanlılar'ınki de bulunacakt1. $^{53}$

Ilhanlı İmparatorlugunun inhilâlı dizerine vuku bulan büyük anarşi esnasında Erzurum ve havalisi Sutay Noyan'ın oglu Emir Hacı Toğay'ın eline geçmiş ve bu Hoca Togay'm oglu Hasan, Erzurum'un doğusundaki Hasan-Kalesi'ni yaptırmıştı. Fakat 1340 yılında Emir Çoban'nın torunu Şeyh- Hasan sâir yapılarla birlikte Hasan-Kalesi'ni de tahrip etmişti.

1340 dan 1358 senesine kadar Çobanlıların elinde kalan Erzurum, bu sene içinde Celayırlılardan Sultan Uveys'in, Tebriz'i işgalini müteakip onların elinden çıkmıştır. ${ }^{54}$

1333-1334 yilları arasında Anadolu'yu gezen ve bu arada Erzurum'a da uğrayan İbn Batlita, bu büyük şehrin mühim bir kısmının iki Türkmen oymağının (Akkoyunlu-Karakoyunlu ) mücadelesi yutzilnden harap bir hale gelmiş olduğunu yazmaktadır. ${ }^{55}$

1360 yllından itibaren Eretna Devleti'nin idaresine geçmiş olduğu bildiğimiz Erzurum Kalesi'nde ve şehirde eserlerinin bulunduğu hakkında şimdiye kadar elimize, bizi aydınlatacak bir vesika geçmemiştir. ${ }^{56}$

Erzurum'un kısa fasılalar hariç uzunca bir müddet Eretna Devleti'nin hâkimiyetinde kaldığı tahakkuk ediyor. Eretna valisi 1385 yıllarına kadar Erzurum'a hâkim olmuş, ondan sonra şehir Karakoyunlular'ın koruyucusu Kara Mehmed'in eline ve hâkimiyetine geçmiştir.

Işte bu sırada Timur, 1389'da Erzurum'a ylurumuşs ve Karakoyunlu Türkmenleri perişan ettikten sonra, "Avnik Kalesi'nden Erzurum'u "bir gün içinde gelip zapt ve yağma etmiştir. ${ }^{57}$

Bir günluk bir savaşla kaleyi ve şehri zapt etmiş ve yağmalamış olan Timur'un, Erzurum'a karşı neden bu kadar acımasız davrandığı Saltuknâme'de aşağıdaki gibi hikâye edilmektedir:

“Timur ve dahi Erzenü'r-Rûmi dahi yıktı. Anlarun fesadı ol idi kim gơtürü ehl-i sûk ve mizan ve hile ve bazar halkı hâkimlerine rîş̧vet kesim virub, narh'ı eksigine satarlardı. Fukara hakkını yirlerdi. Hiyânet zür fesad ve birahm idiler. Pes,

${ }^{53}$ M.H.Yinanç, "Erzunum" Mad. İA, IV, s.350.

${ }^{54}$ Enver Konukçu,Selçuklulardan Cumhuriyete Erzurum, s.86.

${ }^{55}$ İbn Batlita, Seyahatnâme,C.I.( Trc:M.Șerif) İstanbul, 1335, s.329.

${ }^{56}$ M.H.Yinanç "Erzurum" Mad. L̇A.IV,s.350.

${ }^{57}$ Nizamilddin Sami Zafername, ( Trc:Necati Lügal ) Ankara 1987.s.124; O.Turan, Istanbul Fethinden Önce Yazılmıs Tarihi Takvimler, 2. Baskı Ankara 1984,s.81. 
Timur anlanı şöle kurdı kim, beşiğinde oğlancıklan bile öldürdi. Bazılar eyidür. Sivas'da ve Erzenü'r-Rum'da bir zulüm dahi vardı. Kim Hak Te'alâ helâkına ol kavmin anı sebeb itdi. Buydu kim kaçan kediler ve kelbler yavilsalar, sokağa bırakurlard. Kedi ve kelpcugezler çağıru can virürdü. Temür anı işidüb gazab itmesine ol sebeb oldu, dirler. Zira, Timur, ádillik davasin iderdi. Zerre kadar zulme itâb iderem, deyü söylerdu", ${ }^{8}$

1394'de Anadolu'ya tekrar girip, bu arada Avnik Kalesi'ni alan Timur'u 1402 yilında tekrar Erzurum'da görułyoruz. 1402 de gelişinde Tortum Kalesi'ni alarak Erzurum'daki işlerini yoluna koyduktan sonra, buradan ayrılan Timur, Ankara Savaşı akabinde tekrar Erzurum'a uğradı. Bundan sonra Anadolu'dan ayrilurken Erzurum, Avnik, Kars, Ani, Sürmeli, Zivin, Micingert Kalelerine güvendiği kimseleri tayin ettiğinden, buralar bir müddet daha $O$ 'nun nüfuzunda kalacaktir.

Timurluların Erzurum Kalesi'ni tamir ve tahkim ettikleri nuhakkaktur.Bu zamanlarda Erzurum'un nüfusu çok azdı. ${ }^{59}$

Timur'un Erzurum'dan ayrilmasindan biraz sonra 21 Mayıs 1404 de buraya uğrayan, İspanyol Kurah Don Henri'nin elçilik heyeti içindeki Claviyo, Erzurum'un Yusuf Ali isimli Türkmen valisinden bahsettiği gibi, şehrin kuleli sûrlar ile çevrildiğini ve bir iç kalesi bulundư̆unu yazmaktadir. ${ }^{60}$

XIX. Yüzyılda siyasî varlık olarak ortaya çıkan ve 1380-1468 yılları arasında hüküm süren Karakoyunlular ile Timur'un oğlu Şah Ruh (1404-1447) 1421 yllında savaşmış; ve Karakoyunlu İskender'i (1420-1438) Eleşgirt'de yenerek Horasan'a dönmüşstu. Fakat Şah Ruh'un gidişinden sonra geri gelen İskender Bey, Erzurum'u zaptederek, ${ }^{61}$ Duharlu Türkmen boyunun reisi olan pir Ahmed Bey'i, buraya vâli tayin eylemişti. ${ }^{62} 1434$ de Şah Ruh, Karakoyunlulara karşı üçüncü kez yaptığı Azerbaycan Seferi'nde, Akkoyunlu ulusu reisi Kara Yülük Osman Bey'i yardıma çağırmış, o da derhal bulunduğu Diyarbakır'dan, kalabalık bir ordu ile hareketle Erzurum önùne gelerek şehri kuşatmıştı. Erzurum'u Iskender adına idare eden Duharlu Pir Ahmed, şiddetli bir müdafaa gőzterdi ise de; Akkoyunlular kullandıkları mancınıklar ile sur ve burçları dögmeğe ve akabinde de bir gedik açmağa muvaffak olmuşlardı. Mancınıklar, sûrların burçlarından birini de yıktığından, Akkoyunlular şehri almağa muvaffak oldular. ${ }^{63}$

\footnotetext{
${ }^{58}$ Ebû'l Hayri Rumî, Saltuknâme,c.I. (Çvr. S.H. Akalın), Ankara,1967, s.157-158.

${ }^{59}$ Ibn Batuta, Seyahatnâme,c.I s.329; İ.Hakkı Konyalı, a.g.e., s. 109.

${ }^{60}$ Klaviyo, "Timur Devrinde Semerkand'a Seyahat",(Čr. Ö.Rıza Dogrul) İstanbul 1975, s. 78

61 Toma Metsopski; "Timurlenk ve Onun Haleflerinin Tarihi" (Ruscadan Tercume: H.Bakihanov) Bakú 1957, s.33.

${ }^{62}$ M.H. Yinanç, "Erzurum" Mad.IA. IV, s.351.

${ }^{63}$ Ebû Bekr Tihrani, Kitab-1 Diyarbekriyya, C.I (Yay: N. Lugal; F. Sümer) Ankara 1993, s.107-108.
} 
Akkoyunlu Beği Kara Yülük Osman, Erzurum'u oğullarından Şeyh Hasan'a verdi ve bu başarısını Şah-Ruh'a bildirdi. ${ }^{64}$ İskender ise Tebriz'e çekilmişti.

Böylece buyluk bir emir olan Kara Yüluk Osman Bey; Erzurum, Bayburt, İspir, Tercan'a da hâkim olmuş̧tu. ${ }^{65}$

Bu hadiseden biraz sonra, Karakoyunlu İskender Bey, Azerbaycan'a giren Şah Ruh'a karşı koyamayarak geri çekilip, Osmanlı diyârına gitmek üzere Erzurum'a doğru kaçtı. Şah Ruh,Iskender'in Erzurum'a dogru kaçacağını tahmin ettiginden, bu civarda bulunan Akkoyunlu Kara Yülük Osman'a onun yolunu kesmesini bildirdi. $O$ da Erzurum'u tahkim etti. Yaninda az bir kuvvetle, Erzurum 'a doğnu gelen İskender ile Kara Yüluk kuvvetleri arasında Karaz'da çıkan çetin savaşta (1435) başından ağır yaralanan Kara Ytilük, muharebe meydanından getirildiği Erzurum'da vefat etti. ${ }^{66}$ Aynî gibi Memlük müverrihlerinin anlattıklarına göre: Kara Yülük boğazına ugradıktan sonra , Erzurum'a girmek isterken surların kenarlarındaki hendege düşerek ve boynu kırılarak ölmusștur.

Bu savaştan sonra, ağır kayıplar veren Akkoyunlar, beğleri Kara Yüluk'ün ölümü uzzerine Erzurum'dan kaçarak, gittiler. ${ }^{67}$

Timurlu şehzadesi Muhammed Cuki, bu sırada Akkoyunlular.'a yardım için hareketle ancak Pasin'de Aras kenarına kadar gelmişti. Çoban Köprüsü'nú geçen Timurlu askerleri, Karakoyunlular 'in daha fazla zarar ziyan vermesini engellemek için Erzurum'a yürudüler. Karakoyunlular ise, kalenin savunmasız bırakıldığını görünce, geçici olarak Erzurum'u ele geçirdiler. Yani, İskender Erzurum şehrini kalesiyle beraber aldı. Bu arada Kara Yülük Osman'ın kabrini de tahrip ettirdi.

Timurlu kuvveti az sonra Erzurum önlerine gelmege başlarken, İskender de batıya doğru çekiliş emrini vererek, Osmanlı sınırlarına sığındı. Tokat'a kadar giderek kışlayan İskender, Timurlu tehlikesinin azaldığını görerek, sığındığı Osmanlı ülkesinden geri dönerek, Erzurum'a uğradı. Oradan da Avnik-Kağızman yolu ile Sürmeli- Çukuru'na gelerek 1437 kışını orada geçirdi. ${ }^{68}$

Iskender Bey,1438 yılında oğlu Şah Kubat tarafindan öldürüldü. yerine geçen kardeşi Cihan Şah (1438-1476), Karakoyunlular'm son hükümdarıdır.

Sah Ruh'un oglu Cuki, Erzurum kalesini tahkim ve tamir ettirmişti. Karakoyunlu hükümdarı İskender Bey de Erzurum kalesi'ni tamir ve termim ettirmiştir. ${ }^{69}$

${ }^{64}$ Ebû Bekr Tihrani, Kitab-1 Diyarbakriyya, I, 107; John E. Woods, Akkoyunlular, (Çev: Sibel Özbudun) Istanbul 1993 s.71.

${ }^{65}$ Ebù Bekr Tihrani Kitab-1 Diyarbaknyya, I, s.35.

${ }^{66}$ Ebu Bekr Tihrani Kitab-1 Diyarbaknyya, I, 107,111-114,115.

${ }^{67}$ F.Sumer, Karakoyunlular, 2. Baskı Ankara 1984, s.136; John E. Woods, Akkoyunlular s. 95-96.

${ }^{68}$ Ebû Bekr Tihrani, Kitab-1 Diyarbakriyya, I, 126-128.

${ }^{69}$ I.Hakkı Konyalı , Abideler ve Kitabeleri ile Erzurum, s.110-111. 
Karakoyunlu ve Akkoyunlu gibi iki rakip Türkmen devleti arasında zikzaklı bir alınıp verilme akıbetiyle başbaşa kalmış Erzurum'a Akkoyunlular'ın beșinci hükümdarı Uzun Hasan (1453-1478) da sık sık hücumlar yapmı̣s ve fakat bu kaleyi alamamıştır.

Cihan Şah ollünceye kadar Erzurum Karakoyunlular'n elinde ve hakimiyetinde kalmıștır. Ancak Cihan Şah'ın ölümünden hemen sonradır ki Uzun Hasan, 1468 de diğer Karakoyunlu topraklarıyla beraber Erzurum'u da almıştır. Erzurum, Akkoyunlu Devleti'nin son zamanlarına kadar, onların elinde kalmıştır.

1473 de Uzun Hasan, Otlukbeli 'nde yenilince Osmanlılar ebedi olarak Erzurum'a sahip olacaklardır.

XIV. yuzyılın ilk yarısının ortalarında Akkoyunlular'ın yurdu Diyarbakır ve Erganı yöresiydi. Bu civara kuzeyden giden yaz ve kış otlaklarının yolları Kemah, Erzincan, Bayburt ve Erzurum coğrafyasından geçiyordu. Bu anlamda temel göç yolları üzerinde stratjik bir konuma sahip Erzurum, önemli ve çok sayıda daha küçük kalelerin'de denetimini sagllyordu. Bu sebeple Akkoyunlular için çok önemliydi. Çünkü Erzurum, Pasin'den Palu'ya, Ergani'ye kadarki gụçlủ kaleleri;ve göç yolunun denetimini saglaması bakımından bulunmaz nitelikteydi. ${ }^{71}$

Akkoyunlular için bir fetih ve genişleme çağı başlatan Kara Yülük Osman Bey, Karakoyunlu, Kara Yusufun savaşcı oğlu ve varisi İskender'le savaşlar yaparak 1434 de Erzurum'u Karakoyunlular' in elinden geçici de olsa koparmayı başarmıştı. 1454 yılında da Karakoyunlu arazisinden olan Erzurum, Avnik, Bayburt havalisi Akkoyunlular tarafundan talan edilmişti. ${ }^{72}$ Yukarıda da belirtildigi gibi nihayet Erzurum, son Karakoyunlu Cihan Şah'm ölümünden sonra Akkoyunlu idaresine geçince: hem Orta Asya'yı, Hindistan'1, İran'ı batı İslam pazarlarına ve Avrupa'ya bağlayan hayati ticari yollar üzerindeki Akkoyunlu egemenliği sağlamlaştırıldı; hem de doğudaki yazlık yaylalar ve Diyarbakır'daki kışlık bozkırların kesin denetimi saglanmış oldu. ${ }^{73}$

Yavuz Sultan Selim'in Çaldıran'a giderken ve gelirken yakınından geçtiği Erzurum şehir ve kalesi bu yillarda metruk bir kale idi ve tek bir nüfus yoktu. ${ }^{74}$

Kanuni çą̆ında 1534 yılında Osmanlı idari yönetimine katılan Erzurum Kalesi tamir ve tahkim edilmiştir. Mogol istilası neticesinde yağma ve tahribe uğrayan, İhanlıların sukutundan sonra, onun limerası tarafindan: bilâhare Karakoyunlular ' in eline geçen ve bilhassa Karakoyunlu İskender Bey tarafindan bir defa daha iyice yağma ve tahrip edildiginden büsbütün harap halde bulunan Erzurum şehir ve kalesi, 1534 de yeniden te'sis ve iskân edilmiş; istihkâmatı tamir olunmuş

\footnotetext{
${ }^{70}$ L.Hakkı Konyalı, a.g.e.,aynı yer .

${ }^{71}$ John, E. Woods, Akkoyunlular, s.71,77,84.

72 Walther Hinz, Uzun Hasan ve Seyh Cüneyd, (Cev.Fikret Bıylkoglu).Ankara 1992, s.115.

73 John, E.Woods, aynı eser, s.96-97.

${ }^{74}$ I.Hakkı Konyalı, Abideleri ve Kitabeleri ile Erzurum, s. 113.
} 
ve arazisi tahrir edilerek, sipahilere verilmiştir. ${ }^{75}$ Bu arada Erzurum Kalesi'nin yeniden bir surla tahkimi ihtiyacı İstanbul'a bildirilmiş, bu sebeple 12 Nisan 1577 de İstanbul'dan gelen emirde Erzurum Kalesi'nin etrafina tabiyalar yapılması istenmişti. $^{76}$

Erzurum askeri bir şehir olarak kurulmuş ve zaman zaman müdafaasının kuvvetini artırmak için şehrin etrafı ve içi kuleler, yulkssek duvarlarla kat kat tahkim edilmiştir. Doğu Roma (Bizans )İmparatorluğu, Iran 'a karşı iki büyltk şehrin müdafasında çok titiz davranmış, çok ehemmiyet vermiştir. Bu şehirlerin birisi Dıyarbakır, diğeri Erzurum'dur. Böylece iki hakumet arasında hudut olan Erzurum şehri etrafında kanlı savaşlar olmuştur.

Erzurum'da şimdiki halde sağlam olarak kalan İç-Kale'nin duvarlarıla ve bir de ötesinde berisinde görülen sur parçalarindan başka bir şey yoktur. Hatta bu parça surlar şehrin yakın zamanlarında yapılan imâr çalışmalanında ortadan kalkmıştır.

Selçukluların yaptırdıkları kuleler ve yüksek duvarlar da bütün ortadan kalkmıştır. Yalnız Iç-Kale surunun güneye uzanan duvarlarındaki kule kalmıştır ki burada Ebô İshakî Kazrunî yatmaktadrr. ${ }^{7}$

Bugün mevcud olan İç-Kale (zamanında mevcud olan )surların ortasında yükselen tepe üzerinde kurulmuştur. Kale dört kőşedir. Bu kalenin duvarları yüksektir.

Simdi yok olup da eskiden mevcut olan sur duvarlarının yerlerini bir çok araştırmalar neticesi 1936 da eserini yayınlayan A.S. Beygü bularak tarif etmiştir.

İç-Kale'den sonraki ikinci surun duvarı kuzey ve güney taraflarından İç Kale duvarına bitişikti. İkinci ve uçüncü surların üzerinde gerektiğinde konulan ve kaldırılan kőprüler varmış. Surlar şehri düz bir daire şeklinde çevirmemiştir.; bir takım ustúvanî ve kâh kőşeli kuleler (surların ileri çıkıntıları köşeleridir. ) ile desteklenmiştir.

Toplara karşı İç-Kale'nin hedef teşkil ettiği anlaşılınca "XIX.yuzyılda Erzurum surları önemini kaybetmiştir.

İç-Kale'de evvelce bulunmuş olan anbar ve kışla duvarları 1829 Haziran 'ındaki Rusların ilk işgalinde yakılmıştır.

Şimdiki halde mevcud sur parçalarında hiçbir kitabe yoktur. Halbuki Selçuklular Erzurum Kalesi'ne önem vermişler ve burayı daimi surette emniyet altında bulundurmak için Trabzon Rumları'na karşı Bayburt'u Gürcúlere karşı da

75 M.F.Kırzıogiu, Osmanlıların Kafkas Ellerini Fethi (1451-1590) Ankara 1976, s.142; M.H.Yinanc,"Erzurum “, lV,352.

${ }^{76}$ M.F.Kırzıoglu, Osmanlıların Kafkas-Ellerini Fethi (1451-1590), s. 265.

${ }^{77}$ A.Șerif Beygü, Erzurum, Tarihi, Anitlar, Kitabeleri, s.19.

${ }^{78}$ A.Şerif Beygü, a.g.e.,s. 22 
Micingerd. Avnik, Zivin kalelerini çok saglam bir surette yaptıkları düşünülürse, Erzurum Kalesi'nin bunlardan ne kadar ustuin olduğu anlaşlır.

Erzurum İç-Kalesi, hisariçeleri $1853 \mathrm{~K}$ rrm Harbi'nin başlayacał̆ı sıralarda ve harp içinde birinci defa; Kale ve surların ikinci defa olarak yıkılışı da 1865 yulında olmuştur. Bu zamanda çarlığın istilâsına karşı Erzurum'u tutabilmek için o devrin tâbiye usulüne göre şehir yeni baştan istibkâmlarla techiz edilmeğe başlamıştır. Bu çalışma 1877 Harbi'ne kadar devam etmiştir. Bu yeni istihkâmlarda kullanılmak tizere surların kesme taşlan kullanılmış, bu şekilde duvarların mühim bir kısmı yıkılmıştır. ${ }^{79}$

İç-Kale'den ve diğerlerinden birbirlerine ve en sonunda da dişarıya muhtelif kapılar açılırdı..Bu kapıların adları da vakfiyelerde, Mülknâmelerde ve halkın dilinde yaşamaktadır. Bahsedildiği gibi surlardan açılan kapılar şunlardır.: Tebriz Kap1, Gürcü Kapı, Erzincan Kapıs1, Yeni Kapı.

İ̧-Kale doğudan batıya doğru mustatil şekildedir. Kale; Ehmedekliğinden, İç-Kale oluşundan çok bir şey kaybetmeden bize kadar gelmiştir. İç-Kale'nin kale kumandanının, dizdarın ve icabında hükümdarın ve serdarın oturduğu en müstahkem kısmı, Ehmedek'in gliney doğu köşesinde idi. ${ }^{80}$ Buradaki kasır yıkılmış ve yok olmuştur. Yalnız hamamı kalmıştır. Buraya kalenin güney kőssesinden batıya dogru açılan kapıdan girilmektedir. Kapının üstünde bulunan Tuğralı Kitabenin kazınmak suretiyle yok edildiği görülmektedir.

Kale'nin gliney duvarının camiin alt taraflarına, sağına ve soluna rastlayan kısımları yapı malzemesi ve inşâ tarzı itibarnyle kuleye ve mâbede benzemektedir. $O$ halde bu kısım duvarların Saltuklularn kuruyucusu Ebì'l Kasım'ın oğlu İnanç Biygu Alp Tuğrul Bey tarafindan yaptınldığına hiç şüphe yoktur. Yalnız kulenin hemen sağında güneyde, Kurklar Türbesine doğru açılan ve şimdi kapalı bulunan kapı ile duvarların bir kısmının daha sonradan yapılmıs olduğ harcından ve mimari tarzından anlaşılmaktadır. ${ }^{81}$

Evliya Çelebi, Kale Duvarlarının 60 arşın (445.48m.) olduğunu söylüyor.

Erzurum Kalesi'nin İç-Kale'sinde İnanç Biygu Kulesi (Saat Kulesi)'nden başka hiç bir kitabesi bize kadar gelmemiştir. Avrupalı ve Amerikalı bazı seyyahlar ve tarihçiler kale kapılarının üzerinde kitabeleri bulundugunu yazıyorlar. ${ }^{82}$

Erzurum Kalesi'nin kitabeleri bize kadar gelseydi., kale tarihinin bir çok kördüğümleri çözillurdü.

\footnotetext{
${ }^{79}$ A.Şerif Beygit, Erzurum Tarihi, Anıtları, Kitabeleri, s.26.

${ }^{80}$ İ.Hakk1 Konyall, Abideler ve Kitabeleri ile Erzurum, s.93.

${ }^{81}$ İ.Hakk1 Konyall, a.g.e., s.93-94.

82 I.Hakk1 Konyal1,a.g.e., s.95.
} 
1878 den sonra Rusların yapmış oldukları Bakü, Tiflis, Batum demiryolu ile, sonradan bu yol Tebriz, Culfa ile birleşerek Erzurum'un ticaretini azaltmış ve yavaş yavaş ehemmiyetini kaybetmiştir.

Askeri ehemmiyetine gelince: bu böyle degildir. Kalenin ve şehrin kuruluşu askeri bir maksada mebni olduğundan kale, dolayısıyla şehir, kurulduğu zamandan yani 450 senesinden şimdiye kadar bu önemini kaybetmiş değildir.

Bugün Erzurum Kalesi, modası geçmiş antik eşyaların sergilendiği meydanda şehre bakarken, başından geçenleri düşüntuyor halde. Sanki ayası yere basmış bir elin şehâdet parmağı misali; Tepsi Minare'si gőkden uçan kuşlara, ben buradayım, der gibi ...Kim bilir? Sessiz bir dile karşı caddedeki Çifte Minâre ile ne sohbetler yapiyordur... 